\title{
PENHORA DE QUOTAS DE SOCIEDADES PERSONIFICADAS E O DIREITO FUNDAMENTAL À TUTELA JURISDICIONAL EFETIVA ${ }^{1}$
}

\section{GARNISHMENT OF PERSONIFIED LEGAL ENTITIES SHARES AND THE RIGHT TO AN EFFECTIVE JUDICIAL PROTECTION}

Luis Alberto Reichelt Mestre e Doutor em Direito pela UFRGS. Professor nos cursos de graduação, especialização, mestrado e doutorado em Direito da PUCRS. Procurador da Fazenda Nacional em Porto Alegre (RS). luis.reichelt@pucrs.br

Alexandra Mattos Mestranda em Teoria Geral do Processo e da Jurisdição pela PUCRS. Especialista em Direito Empresarial pela PUCRS. Advogada. Porto Alegre/RS. alexandra.silva.001@acad.pucrs.br

RESUMO: O presente estudo busca investigar a penhora de quotas de sociedades personificadas no novo $\mathrm{CPC}$, analisando o tema na perspectiva do direito fundamental à tutela jurisdicional efetiva. São examinadas as principais dificuldades decorrentes da expropriação de quotas de sociedades nas quais se faça relevante a affectio societatis, bem como da necessidade de preservação da atividade empresarial. Sustenta-se que as respostas a serem construídas para o enfrentamento de tais dificuldades passam sempre pela reflexão em torno do impacto dos direitos fundamentais das partes na conformação do sistema jurídico processual.

PALAVRAS-CHAVE: Processo Civil - direito fundamental - efetividade - penhora.

\footnotetext{
${ }^{1}$ Artigo recebido em 11/07/2017 e aprovado em 19/11/2017.
} 
Revista Eletrônica de Direito Processual - REDP.

Rio de Janeiro. Ano 11. Volume 18. Número 3. Setembro a Dezembro de 2017

Periódico Quadrimestral da Pós-Graduação Stricto Sensu em Direito Processual da UERJ

Patrono: José Carlos Barbosa Moreira. ISSN 1982-7636. pp. 219-237

www.redp.uerj.br

ABSTRACT: The present study aims to investigate legal entities share's garnishment in the new Brazilian Civil Procedure Rules, under the perspective of the right to a effective judicial protection. It examines the main difficulties related to the entities' shares expropriation in cases in which the affection societatis is considered a relevant factor, so as the urge of the business activities preservation. It is sustained that the right answers on facing such difficulties always are related to the impact of the parties fundamental rights over the procedural juridical system conformation.

KEYWORDS: Civil Procedure - fundamental right - effectiveness - garnishment.

SUMÁRIO: 1. Introdução. 2. A responsabilidade patrimonial do executado (a) que é sócio (a) de uma pessoa jurídica e a preocupação com a continuidade da atividade empresarial da pessoa jurídica de que ele (a) é sócio (a): uma leitura à luz da conjugação dos artigos 797 e 805 do CPC/2015. 3. Os problemas relativos ao procedimento da penhora e alienação de quotas de ações de sociedades personificadas na perspectiva dos direitos fundamentais das partes. 4. Conclusão. 5. Referências Bibliográficas.

\section{Introdução.}

A penhora de quotas de sociedades personificadas não é um tema fácil de ser abordado, por entrelaçar dimensões situadas no plano do Direito Material e do Direito Processual. Nela fundem-se reflexões das mais complexas situadas no âmbito do Direito Societário, em especial no que tange ao impacto exercido pela affectio societatis como fator a justificar o entrelaçamento dos sócios em torno de uma atividade empresarial, e do Direito Processual Civil, com ênfase na preocupação constante com a efetividade da providência em questão no contexto da execução por quantia certa contra devedor solvente.

Com a entrada em vigor do novo Código de Processo Civil, o debate ganha novo fôlego, vez que houve atual regulamentação acerca do tema, inexistente nos diplomas legais até então existentes. Essa novel regulamentação ganha ares peculiares em se considerando a necessidade de sua análise à luz da exigência de adequação do novo sistema processual ao paradigma dos direitos fundamentais processuais, vetor que influencia de maneira transversal a conformação do processo de execução. 
Revista Eletrônica de Direito Processual - REDP.

Rio de Janeiro. Ano 11. Volume 18. Número 3. Setembro a Dezembro de 2017

Periódico Quadrimestral da Pós-Graduação Stricto Sensu em Direito Processual da UERJ

Patrono: José Carlos Barbosa Moreira. ISSN 1982-7636. pp. 219-237

www.redp.uerj.br

Tomando em conta esse panorama acima transcrito, propõe-se seja investigada

a regulamentação da penhora sobre quotas de sociedade personificada sob o prisma do direito fundamental à tutela jurisdicional efetiva. Nesse sentido, analisar-se-á, em primeiro lugar, o debate sobre a responsabilidade patrimonial do executado que é sócio de uma pessoa jurídica e a preocupação com a continuidade da atividade empresarial da pessoa jurídica de que o executado é sócio, fazendo-se uma leitura à luz da conjugação dos artigos 797 e 805 do Código de Processo Civil/2015. Cumprida essa etapa, passa-se ao exame dos problemas relativos ao procedimento da penhora e alienação de quotas de ações de sociedades personificadas no novo CPC, refletindo-se sobre a compatibilidade dessa sistemática processual com a perspectiva dos direitos fundamentais das partes.

\section{A responsabilidade patrimonial do executado (a) que é sócio (a) de uma pessoa} jurídica e a preocupação com a continuidade da atividade empresarial da pessoa jurídica de que ele (a) é sócio (a): uma leitura à luz da conjugação dos artigos 797 e 805 do CPC/2015.

A possibilidade de penhora de quotas de sociedade pertencentes ao executado pressupõe a consideração de uma série de perspectivas relevantes.

Um primeiro olhar a ser tomado em conta é o que aponta no sentido de que a tutela jurisdicional executiva stricto sensu transita em um contexto no qual duas exigências antagônicas se entrelaçam. De um lado, o art. 797 do Código de Processo Civil, a execução realiza-se no interesse do credor, em um claro indicativo em favor da exigência de efetividade do processo ${ }^{2}$. De outra banda, a teor do art. 805 do mesmo diploma processual, quando por vários meios o exequente puder promover a execução, o juiz mandará que se faça pelo modo menos gravoso para o executado ${ }^{3}$.

Conforme ensina Marcelo Abelha, "não é justo nem legítimo submeter o executado (seu patrimônio) a uma situação de maior onerosidade do que a que seria

\footnotetext{
${ }^{2}$ A respeito da exegese do comando legal citado, ver as considerações de Sergio Mattos, in WAMBIER, Teresa Arruda Alvim, DIDIER JR, Fredie, TALAMINI, Eduardo e DANTAS, Bruno (org.). Breves Comentários ao Novo Código de Processo Civil. São Paulo: Revista dos Tribunais, 2015. p. 1822 e seguintes.

${ }^{3}$ Segundo Sergio Mattos, "a serviço da satisfação efetiva do exequente, a execução, por si só, já onera, sacrifica ou prejudica, em certa medida, o executado ou seu patrimônio" (in WAMBIER, Teresa Arruda Alvim, DIDIER JR, Fredie, TALAMINI, Eduardo e DANTAS, Bruno (org.). Breves Comentários ao Novo Código de Processo Civil. Op. cit., p. 1872).
} 
Revista Eletrônica de Direito Processual - REDP.

Rio de Janeiro. Ano 11. Volume 18. Número 3. Setembro a Dezembro de 2017

Periódico Quadrimestral da Pós-Graduação Stricto Sensu em Direito Processual da UERJ

Patrono: José Carlos Barbosa Moreira. ISSN 1982-7636. pp. 219-237

www.redp.uerj.br

indispensável para a satisfação do direito do exequente"4. A fórmula legal é semelhante, mas não exatamente igual ao estabelecido pelo postulado da proporcionalidade em seu segundo nível de análise, que é o da necessidade. Se de um lado a exigência de proporcionalidade impõe que se considere a existência de outros meios igualmente eficazes que sejam capazes de gerar menor restrição a direitos fundamentais do que aqueles considerados para análise ${ }^{5}$, de outra banda é certo que a letra da lei estabeleceu um ônus mais exigente ao executado, dele exigindo a indicação de outros meios mais eficazes em favor do exequente e menos onerosos para o executado.

Eis, pois, que o resultado desejado do ponto de vista do direito à tutela jurisdicional efetiva, consagrado no art. $5^{\circ}, \mathrm{XXXV}$ da Constituição Federa ${ }^{6} 1$, pressupõe o enfrentamento de uma primeira equação a ser solucionada, qual seja a que exige verificar se a penhora de quotas atende a ambas as exigências impostas pelo legislador. A resposta a tal indagação, contudo, reclama um raciocínio com ulteriores desdobramentos.

Nesse sentido, é de se anotar que o art. 789 do CPC/2015 dispõe que o devedor responde com todos os seus bens presentes e futuros para o cumprimento de suas obrigações, salvo as restrições estabelecidas em lei. É sob esse pano de fundo que se observa que, correspondendo a quota social a um tipo de patrimônio do sócio, por ter conteúdo econômico, permite-se a sua penhora para fins de satisfação dos interesses do exequente $^{7}$.

De outro lado, lembre-se que, no início de suas atividades, as sociedades precisam investir em recursos como máquinas, tecnologia, serviços e demais meios indispensáveis ao desenvolvimento da atividade empresária. Uma das formas de obtenção desses recursos é a transferência pelos sócios, com diminuição do seu patrimônio próprio, da propriedade de dinheiro, bem ou crédito, bens que se transformarão em quotas sociais,

\footnotetext{
${ }_{5}^{4}$ ABELHA, Marcelo. Manual de Execução Civil. $5^{\text {a }}$ edição. Rio de Janeiro: Forense, 2015. p. 63

5 Sobre o postulado da proporcionalidade, ver ÁVILA, Humberto. Teoria dos princípios. São Paulo: Malheiros, 2003. p. 104 e seguintes.

6 Sobre o conteúdo do direito fundamental à tutela efetiva, ver, exemplificativamente, BARBOSA MOREIRA, José Carlos Barbosa. Efetividade do processo e tecnica processual. Revista de Processo, vol. 77 (1995): 168-176; BARBOSA MOREIRA, José Carlos. Efetividade do processo: Por um processo socialmente efetivo. Revista Sintese de Direito Civil e Processual Civil. vol. 11 (2001): 5-14; MARINONI, Luiz Guilherme. A legitimidade da atuação do juiz a partir do direito fundamental à tutela jurisdicional efetiva. In: MEDINA, José Miguel Garcia; CRUZ, Luana Pedrosa de Figueiredo; CERQUEIRA, Luís Otávio Sequeira De; Gomes Júnior, Luiz Manoel (coord.)..Os poderes do juiz e o controle das decisões judiciais: estudos em homenagem à professora Teresa Arruda Alvim Wambier, São Paulo : Rev. dos Tribunais, 2008. p. 229-236.

${ }^{7}$ GRAZIANI, Alessandro. Diritto delle societá. 5.ed.Nápoli:Morano, 1963, p.454
} 
Revista Eletrônica de Direito Processual - REDP.

Rio de Janeiro. Ano 11. Volume 18. Número 3. Setembro a Dezembro de 2017

Periódico Quadrimestral da Pós-Graduação Stricto Sensu em Direito Processual da UERJ

Patrono: José Carlos Barbosa Moreira. ISSN 1982-7636. pp. 219-237

www.redp.uerj.br

as quais serão integralizadas à sociedade. No caso das sociedades anônimas, este investimento dos sócios forma o capital social da companhia que será dividido em forma de ações entre os sócios acionistas ${ }^{8}$. Sob a ótica da sociedade, as quotas são os contingentes de bens com os quais os sócios contribuem ou se obrigam a contribuir para a sociedade. ${ }^{9}$ Sob o ponto de vista dos sócios, as quotas representam direitos e obrigações inerentes à sua condição de sócio ${ }^{10}$.

De se lembrar, ainda, que o princípio da preservação da empresa e a affectio societatis são elementos basilares do Direito Empresarial, pressupondo a intenção dos sócios de formar a sociedade, de zelar por ela, impondo-se a todos um dever de colaboração em busca do mesmo fim ${ }^{11}$.

Partindo dessas premissas, é de se concluir com a doutrina que a quota social constitui patrimônio do sócio devedor e, portanto, está sujeita a restrição judicial objetivando a satisfação dos credores ${ }^{12}$. Em que pese a legislação processual vigente também reafirme tal possibilidade, importante ressaltar que isso não ocorre sem que se exija maior reflexão ulterior.

Muito já se discutiu a respeito da penhorabilidade das quotas sociais, notadamente quando vigente o Decreto 3.708/19, que regulamentava a constituição de sociedades por quotas de responsabilidade limitada. A esse respeito, alguns autores defendem a ideia de que as quotas sociais só poderiam ser penhoradas se admitida a entrada de novos sócios, sob pena de violar a personificação da sociedade. Nesse sentido, leciona Rubens Requião que "as quotas só poderiam ser penhoradas se fosse livre a entrada de novos sócios, o terceiro que arrematou a quota poderia ser impedido de ingressar na sociedade pelos demais sócios, com base na cláusula contratual restritiva"13.

\footnotetext{
${ }^{8}$ COELHO, Fábio Ulhoa. Curso de Direito Comercial. Direito de Empresa. Vol. 2. 15 ${ }^{\text {a }}$ ed. São Paulo: Saraiva, 2011. p.180.

9 Acerca da execução contra os bens do sócio leciona Araken de Assis: "Se o credor, afirmando haver responsabilidade solidária ou subsidiária, pede que a penhora recaia sobre bem de sócio do devedor, tem-se pedido de execução formulado contra este. Do conceito de parte adotado, decorre que ele é réu". (ASSIS, Araken de. Manual da Execução. 13a ed., São Paulo: Revista dos Tribunais, 2006,p.231).

${ }^{10}$ TOMAZETTE. Marlon. Curso de Direito Empresarial. Teoria Geral e Direito Societário. Vol. I. $3^{\mathrm{a}}$ ed. São Paulo: Atlas, 2011. p. 344.

${ }^{11}$ SIMÃO FILHO, Adalberto. A Nova Sociedade Limitada. Barueri-SP: Manole, 2004. p.18/19.

${ }^{12}$ TOMAZETTE. Marlon. Curso de Direito Empresarial. Teoria Geral e Direito Societário. Vol. I. $3^{\mathrm{a}}$ ed. São Paulo: Atlas, 2011. p. 347.

${ }^{13}$ REQUIÃO, Rubens. Aspectos modernos de Direito Comercial. I. São Paulo, Saraiva: 1977. p. $422-423$.
} 
Revista Eletrônica de Direito Processual - REDP.

Rio de Janeiro. Ano 11. Volume 18. Número 3. Setembro a Dezembro de 2017

Periódico Quadrimestral da Pós-Graduação Stricto Sensu em Direito Processual da UERJ

Patrono: José Carlos Barbosa Moreira. ISSN 1982-7636. pp. 219-237

www.redp.uerj.br

A doutrina aponta, ainda, que a penhora de quotas sociais poderia violar a natureza "personalista" da sociedade ${ }^{14}$.

Ao se permitir a penhora de quotas pelo credor, cria-se um perigoso problema dentro da esfera da sociedade, pois a penhora de quotas pelo credor pode ser a porta de entrada para o ingresso de uma pessoa estranha à relação social, violando o caráter pessoal de certas sociedades empresárias. Há um potencial conflito de direitos do credor, devedor e demais sócios: assim como o credor tem o direito de ver satisfeita a sua dívida através da penhora de quotas sociais e o devedor de se ver livre da sua dívida, os demais sócios da sociedade têm o direito de não aceitar uma pessoa estranha à relação societária, inclusive sob pena de violação ao princípio da affectio societatis $^{15}$, norteador das relações empresariais.

Nesse sentido, em importante julgado acerca do tema, o Superior Tribunal de Justiça decidiu que, em que pese reconhecida a possiblidade da penhora de quotas sociais como forma de dar privilégio aos interesses do credor, os efeitos da penhora incidente sobre as quotas sociais devem ser determinados levando-se em consideração os princípios societários. Destarte, havendo restrição ao ingresso do credor como sócio, deve-se facultar à sociedade, na qualidade de terceira interessada, remir a execução, remir o bem ou concedê-la e aos demais sócios a preferência na aquisição das quotas, a tanto por tanto, assegurando-se ao credor, não ocorrendo solução satisfatória, o direito de requerer a dissolução total ou parcial da sociedade. ${ }^{16}$

Há vozes na jurisprudência sustentando ser excepcional a possibilidade de penhora de quotas sociais, alertando para a circunstância de que a satisfação do credor mediante a penhora das quotas do sócio devedor não pode acarretar no desmembramento da sociedade, cujo patrimônio não se confunde com o do sócio devedor nem responde

\footnotetext{
${ }^{14}$ Segundo Fábio Ulhoa Coelho, “da personificação das sociedades empresárias decorre o princípio da autonomia patrimonial, que é um dos elementos fundamentais do direito societário. Em razão desse princípio, os sócios não respondem, em regra, pelas obrigações da sociedade" (COELHO, Fábio Ulhoa. Curso de Direito Comercial. Direito da Empresa. v. 2, 15ª ed. São Paulo: Ed. Saraiva, 2011..p.34).

${ }^{15}$ De acordo com Vera Helena de Mello Franco, "affectio societatis significa confiança mútua e vontade de cooperação conjunta, a fim de obter determinados benefícios." (FRANCO, Vera Helena de Mello. Lições de Direito Comercial. 2.ed. São Paulo: Maltese, 1995, p.133).

${ }_{16}$ Recurso Especial $n^{\circ}$ 221.665/SP, Relatora Ministra Fátima Nancy Andrighi, julgado pela Terceira do Superior Tribunal de Justiça em 07/05/2011
} 
Revista Eletrônica de Direito Processual - REDP.

Rio de Janeiro. Ano 11. Volume 18. Número 3. Setembro a Dezembro de 2017

Periódico Quadrimestral da Pós-Graduação Stricto Sensu em Direito Processual da UERJ

Patrono: José Carlos Barbosa Moreira. ISSN 1982-7636. pp. 219-237

www.redp.uerj.br

pelas suas dívidas. Por esta análise, a penhora de quotas poderia acarretar em surgimento de risco de lesão grave e de difícil reparação para a sociedade ${ }^{17}$.

Percebe-se, nesse sentido, uma preocupação com a garantia do princípio de personificação das pessoas jurídicas, que pode restar violado a partir da penhora de quotas sociais, de modo que, segundo determinou o Superior Tribunal de Justiça, deve ser dada à sociedade, na figura dos demais sócios, o direito de escolher se querem que o credor venha integrar ou não a sociedade a partir das quotas penhoradas do sócio devedor. Assim ocorre na medida em que o ingresso sem maiores critérios de um sócio (como no caso do credor que penhora a integralidade da quota social do sócio executado) pode acarretar em medida em desacordo com os fins da sociedade, tumultuando a affectio societatis que move a continuidade da sociedade empresarial ${ }^{18}$. Reitere-se, com Mauro Rodrigues Penteado, que a desinteligência entre os sócios ou quebra da affectio societais acarreta profundos prejuízos à harmonia da vida societária ${ }^{19}$.

$\mathrm{Na}$ opinião de Sérgio Campinho ${ }^{20}$, Nelson $\mathrm{Abrão}^{21}$. Jorge Lobo $^{22}$ e José Waldecy Lucena, a penhora de quotas é perfeitamente possível, ressalvando a possibilidade da prerrogativa levantada pelo Superior Tribunal de Justiça no julgado acima trazido $^{23}$. Sérgio Campinho refere que havendo liberdade de cessão de quotas, o eventual arrematante pode ingressar livremente na sociedade. Segundo o citado autor, caso haja restrições a esta livre cessão pelos demais sócios, deve-se garantir à sociedade o direito de remir a execução, bem como aos demais sócios deve restar garantido o direito de

\footnotetext{
${ }^{17}$ Agravo de Instrumento ${ }^{\circ}$ 6426615, Relator Antenor Demeterco Junior, julgado pela Sétima Câmara Cível do Tribunal de Justiça do Paraná em 26/04/2011.

${ }^{18}$ De acordo com Moacir Adiers,"a affectio societatis se desenvolve também através de deveres comuns e recíprocos, impostos à observância dos sócios no plano dinâmico do efetivo desenvolvimento da atividade da sociedade, na realização do seu objeto e para a permanência do espírito societário e da própria sociedade" (ADIERS, Moacir. Dissolução parcial de sociedade civil por quotas de responsabilidade limitada. Revista Jurídica, $n^{\circ} 280$ (2001): 61-72, especialmente p.65).

${ }^{19}$ PENTEADO, Mauro Rodrigues. Dissolução e Liquidação de Sociedades: Dissolução Parcial. v.1. 2a ${ }^{\mathrm{a}}$. ed. São Paulo: Saraiva, 2000. p.155.

${ }^{20}$ CAMPINHO, Sérgio. O Direito de Empresa à luz do novo Código Civil. 4 ed. Rio de Janeiro: Renovar, 2004. p. 194

${ }^{21}$ ABRÃO, Nelson, Sociedades limitadas. Atualizado por Carlos Henrique Abrão. 9. ed. São Paulo: Saraiva, 2005. p. 109

${ }^{22}$ LOBO, Jorge. Sociedades limitadas. Vol.1. Rio de Janeiro: Forense, 2004. p.159

${ }^{23}$ LUCENA, José Waldecy. Das sociedades limitadas. 6.ed. Rio de Janeiro: Renovar, 2004. p.383.
} 
Revista Eletrônica de Direito Processual - REDP.

Rio de Janeiro. Ano 11. Volume 18. Número 3. Setembro a Dezembro de 2017

Periódico Quadrimestral da Pós-Graduação Stricto Sensu em Direito Processual da UERJ

Patrono: José Carlos Barbosa Moreira. ISSN 1982-7636. pp. 219-237

www.redp.uerj.br

preferência na aquisição das quotas penhoradas. Refere ele, ainda, que caso nada disso ocorra, o arrematante das quotas sociais ingressará livremente na sociedade. ${ }^{24}$

A investigação em perspectiva histórica confirma a orientação antes apontada.

Desde o advento da Lei 11.382/2006, que reformou o Código de Processo Civil de 1973, a penhora de quotas sociais já era permitida, desde que observada a preferência dos sócios na aquisição das quotas ${ }^{25}$.

Vale lembrar, nesse sentido, que o advento da Lei 11.382/2006 junto ao ordenamento jurídico brasileiro representeou substancial alteração na sistemática da liquidação e execução de títulos judiciais, cujo enfoque principal foi o de simplificar o procedimento da execução, contribuindo à consecução do objetivo de acelerar a entrega da tutela jurisdicional executiva. ${ }^{26} \mathrm{O}$ referido diploma legal modificou a redação do artigo 655 ao CPC/1973, estabelecendo novo rol de preferências para a efetivação da penhora, permitindo, no novel inciso VI, a penhora de ações e quotas de sociedades empresárias. Essa sistemática restou mantida no Código de Processo Civil vigente, nos termos dos arts. 799 , VII, 861 e $876, \$ 7^{\circ}{ }^{27}$

A fórmula em questão expressa, de maneira análoga, o entendimento esposado em recente julgado do Tribunal de Justiça do Estado do Rio Grande do Sul no qual se reconheceu o direito do executado de sofrer a execução de maneira menos gravosa sem, contudo, que isso importasse em desonerar o exequente da tarefa de indicar novos meios à execução menos gravosos do que a penhora de suas quotas sociais, espelhando as exigências de colaboração e da razoabilidade ${ }^{28}$.

\footnotetext{
${ }^{24}$ CAMPINHO, Sérgio. O Direito de Empresa à luz do novo Código Civil. 4 ed. Rio de Janeiro: Renovar, 2004. p. 194

${ }^{25}$ ASSIS, Araken de. Manual da Execução. $13^{\mathrm{a}}$ ed., São Paulo: Revista dos Tribunais, 2006, p. 231-233.

${ }^{26}$ ASSIS, Araken de. Cumprimento da sentença. Rio de Janeiro, Forense, 2006, p. 270-271.

${ }^{27}$ Luiz Guilherme Marinoni, Sergio Cruz Arenhart e Daniel Mitidiero anotam que, "sob o ponto de vista processual, a dissolução parcial de sociedades, antes do atual Código de Processo Civil, era regida por regras do CPC/1939 (especialmente, seu art.668), aplicável na vigência do Código de Processo Civil de 1973 por conta do contido no art. 1.218, VII deste último diploma legal revogado. Vê-se, portanto, que antes da edição do Código de Processo Civil de 2015 a questão da liquidação das sociedades era tratada por regras claramente desatualizadas, e elaboradas a partir de premissas fixadas no início do século passado. Sem dúvidas, essa disciplina era insuficiente e reclamava atualização. Por isso, o Código de Processo Civil atual preocupou-se em desenhar procedimento mais moderno para a medida de dissolução parcial de sociedades, tentando adequá-los às exigências do Código Civil e de praxe recente". (MARINONI, Luiz Guilherme; ARENHART, Sérgio Cruz; MITIDIERO, Daniel. Novo Curso de Processo Civil. v.3. $2^{\mathrm{a}}$ ed. São Paulo: Revista dos Tribunais, 2016. p.183).

${ }^{28}$ Agravo de Instrumento n ${ }^{\circ} 70073168445$, Relator: Heleno Tregnago Saraiva julgado pela $18^{\text {a }}$ Câmara Cível do Tribunal de Justiça do Rio Grande do Sul em 29/06/2017.
} 
Revista Eletrônica de Direito Processual - REDP.

Rio de Janeiro. Ano 11. Volume 18. Número 3. Setembro a Dezembro de 2017

Periódico Quadrimestral da Pós-Graduação Stricto Sensu em Direito Processual da UERJ

Patrono: José Carlos Barbosa Moreira. ISSN 1982-7636. pp. 219-237

www.redp.uerj.br

Os prejuízos advindos da sucessão decorrente da penhora de quotas podem se

projetar, ainda, em diversas outras dimensões da continuidade da atividade empresária, afetando desde a prestação de seus serviços até o pagamento de outros fornecedores ou a manutenção de seus funcionários. Aqui é possível encontrar um motivo a sustentar o acerto da escolha do legislador ao elencar, no art. 861 do Código de Processo Civil, diversos meios para a sociedade se recompor, seja pelo direito de preferência, seja na concessão de prazos (inclusive dilatórios) para apresentar balanço especial e oferecer as quotas ou as ações aos demais sócios.

Não se pode olvidar, ainda, do que dispõe o artigo 1.026 do Código Civil/2002, o qual relativiza a aplicabilidade da penhora de quotas nos casos de sociedades simples. De acordo com o citado comando legal, é assegurado aos sócios que, na ausência de outros bens, a penhora pode recair sobre o direito do sócio aos lucros, ou sobre o direito do sócio sobre o patrimônio social em caso de liquidação. De se observar que, em tal caso, não se cogita da penhora de quotas, mas apenas da penhora dos direitos patrimoniais dos sócios decorrentes da sua participação de sócio, correspondentes à participação nos lucros e no acervo social. A fórmula em questão serve como alternativa a afastar os problemas decorrentes dos riscos de entrada arbitrária de um terceiro na relação societária ${ }^{29}$.

Nessa perspectiva, vale lembrar que apesar do artigo 1.026 do CC/2002 estar elencado dentro da disciplina de sociedade simples, tal dispositivo também pode ser aplicado as sociedades limitadas, por força do artigo 1.053 do CC/2002.

Observe-se, por fim, que o que foi elencado nos tópicos acima diz respeito às sociedades por quotas de responsabilidade limitada, enquanto a previsão do Código Civil ora elencada, diz respeito às sociedades por cotas de responsabilidade limitada ${ }^{30}$. A dificuldade a ser considerada, contudo, é no sentido de que não haveria a possibilidade de um terceiro (o credor) ingressar na sociedade simples, mas apenas de rever o valor patrimonial da quota. Vale destacar, nesse sentido, o Enunciado 388 da IV Jornada de Direito Civil que assim estabeleceu: “O disposto no art. 1.026 do Código Civil não exclui a possibilidade de o credor fazer recair a execução sobre os direitos patrimoniais da quota de participação que o devedor possui no capital da sociedade."

\footnotetext{
${ }^{29}$ TOMAZETTE. Marlon. Curso de Direito Empresarial. Teoria Geral e Direito Societário. Vol. I. $3^{\mathrm{a}}$ ed. São Paulo: Atlas. 2011. p.347.
} 
Revista Eletrônica de Direito Processual - REDP.

Rio de Janeiro. Ano 11. Volume 18. Número 3. Setembro a Dezembro de 2017

Periódico Quadrimestral da Pós-Graduação Stricto Sensu em Direito Processual da UERJ

Patrono: José Carlos Barbosa Moreira. ISSN 1982-7636. pp. 219-237

www.redp.uerj.br

A luz do debatido tema, Alfredo de Assis Gonçalves Neto salienta que o artigo

1.026 do CC/2002 tem sua redação baseada no art. 2.270 do Código Civil italiano. Essa redação, contudo, não se revelaria adequada, uma vez que privilegia o individualismo dos tempos na qual foi editada, não mais condizente com as preocupações dos dias atuais, sendo refratária ao princípio da preservação da empresa. Essa disposição foi alterada na grande reforma do Livro V, em 2004, passando-se, na Itália, a admitir amplamente a penhora de quotas no ambiente das sociedades limitadas (art.2.471). ${ }^{31}$

No Brasil, nota-se antiga discussão quanto a possibilidade ou não de se permitir a penhora de quotas sociais dentro do ordenamento jurídico pátrio que, desde o tempo da elaboração do anteprojeto do Código Civil de 2002, já trazia dita celeuma de forma muito acesa, sempre vista como algo ruim. Contudo, em que pese a maioria doutrinária reagisse de forma contrária a penhora das quotas (defendendo-se a sua impenhorabilidade), no início da década de 1970, a doutrina e a jurisprudência reagiram de modo a se inclinarem em favor da admissibilidade da penhora das quotas sociais também na esfera das sociedades simples, ainda que não houvesse mudança do texto de lei que a regulava $^{32}$.

Luis Gastão Paes de Barros Leães levanta a possibilidade da penhora das quotas sociais, desde que esgotadas todas as formas de execução, ou seja, desde que não existam mais bens do devedor a penhorar, o que vem sendo ratificado pela jurisprudência até os dias atuais. Para o autor, definida a quota social como um bem imaterial, ou seja, definida como um objeto único que é o direito de quota (cujo conteúdo é demasiadamente complexo), por parte do sócio não há como lhe recusar a possibilidade de penhora, assim como é suscetível de penhora a ação de uma sociedade anônima, em que se materializa o direito de participação do acionista. ${ }^{33}$

Interpretando o artigo 1026 do CC e o Enunciado 388 da Jornada de Direito Comercial, anota Luis Gastão Paes de Barros Leães que a penhora de quotas só recai sobre os direitos patrimoniais da quota, de modo que se tais quotas forem a leilão, quem as adjudicará não estará adquirindo o direito de ser sócio, mas sim, tão somente o direito de

\footnotetext{
${ }^{31}$ GONÇALVES NETO. Alfredo de Assis. Direito de Empresa. $3^{a}$ ed. São Paulo: Revista dos Tribunais, 2010. p.243-244

${ }^{32}$ GONÇALVES NETO. Alfredo de Assis. Direito de Empresa. $3^{\text {a }}$ ed. São Paulo: Revista dos Tribunais, 2010. p. 244

${ }^{33}$ LEÃES, Luiz Gastão Paes de Barros. Exclusão extrajudicial de sócio em sociedade por quotas. Revista de Direito Mercantil: Industrial, Econômico e Financeiro, vol. 100 (1995): 85- 97, especialmente p. 83-97.
} 
Revista Eletrônica de Direito Processual - REDP.

Rio de Janeiro. Ano 11. Volume 18. Número 3. Setembro a Dezembro de 2017

Periódico Quadrimestral da Pós-Graduação Stricto Sensu em Direito Processual da UERJ

Patrono: José Carlos Barbosa Moreira. ISSN 1982-7636. pp. 219-237

www.redp.uerj.br

receber os valores em dinheiro que as quotas outorgam de seu titular. Isso é alcançado pela

redução a dinheiro que a quota representa em termos patrimoniais, mais precisamente pela

liquidação, onde se converterá a quota em dinheiro mediante a apuração dos haveres que

representa. A penhora de quotas sociais resultaria, sob essa ótica, em procedimento de

dissolução parcial de sociedade para fins de apuração de haveres do sócio devedor, nos

termos dos artigos 599, III e 604, do Código de Processo Civil ${ }^{34}$.

Em decisão acerca do tema, o Superior Tribunal de Justiça firmou entendimento no sentido de que quando a sociedade se encontrar em funcionamento regular e não existirem lucros a distribuir, o credor do sócio poderá requerer, judicialmente, a liquidação das quotas do sócio devedor, na proporção necessária à satisfação de seu crédito, de acordo com o procedimento de liquidação previsto no art. 1.031 do Código Civil. Portanto, havendo lucros, procede-se à penhora destes para satisfação do credor $^{35}$. Veja-se, pois, é clara a intenção do Superior Tribunal de Justiça em

\footnotetext{
34،“(...) qualquer que seja a razão da dissolução parcial, uma consequência será inafastável: o dever da sociedade em restituir o valor da quota daquele que deixa a sociedade. Em linhas muito gerais, pode-se dizer que esse é o principal objeto da demanda de dissolução parcial de sociedades: a apuração do valor devido ao sócio que perde o vínculo com a sociedade (...) Em verdade, a grande função desta demanda - e o seu diferencial em relação ao procedimento comum - é o oferecimento de ferramentas ao magistrado para que possa definir duas questões que são essenciais no processo de apuração de haveres do sócio que deixa a sociedade: a forma de apuração do valor das quotas devidas e o momento em que se deve ter por ocorrida a dissolução parcial" (MARINONI, Luiz Guilherme; ARENHART, Sérgio Cruz; MITIDIERO, Daniel. Novo Curso de Processo Civil. v.3. $2^{\mathrm{a}}$ ed. São Paulo: Revista dos Tribunais, 2016. p.185).

${ }^{35}$ Nas palavras do Min. Luiz Felipe Salomão, “deve-se considerar que a quota social representa um valor patrimonial e também uma posição dentro da sociedade. Em vista disto e, em especial, do caráter pessoal das sociedades simples, é preciso reforçar que a quota como valor patrimonial deve satisfazer o credor pessoal do sócio, mas não pode interferir no bom andamento dos negócios sociais. Sob esta perspectiva, GIUSEPPE FERRI escreve que: "L'azione executiva del creditore particulare puó quindi unicamente sui diritti che competono al socio debitore e non anche determinare la sostituzione del creditore al debitore nella posizione di socio." Esta foi a justificativa apresentada pelo relator do projeto, para a introdução desta nova figura jurídica. Entende-se, então, que este não era, realmente, o intuito do legislador. Nas palavras do relator do projeto, a premissa para que ocorra a liquidação é a seguinte: "Se esta sociedade se encontrar em funcionamento regular, ou seja, se não estiver dissolvida, e não existirem lucros a distribuir, o credor do sócio poderá requerer, judicialmente, a liquidação das quotas do sócio devedor, na proporção necessária à satisfação de seu crédito, de acordo com o procedimento de liquidação previsto no art. 1.031 do Código" (grifos nossos). Ou seja, para que se implemente a condição a fim de que seja concedida a liquidação, deve a sociedade não só estar em funcionamento, mas também não existir lucros a distribuir. Portanto, havendo lucros, procede-se à penhora destes para satisfação do credor. Esta é uma interpretação que tenta harmonizar os interesses da sociedade, dos sócios e dos credores, da forma menos gravosa. Ademais, acreditar no outro posicionamento, que diz que o credor particular do sócio pode escolher se vai receber os lucros ou se vai liquidar parte da sociedade como forma de pagamento do que lhe é devido, seria condenar as sociedades a um futuro incerto e possivelmente desastroso, caso a diminuição de capital afete sua capacidade produtiva. Nessa última situação acabaria, ainda, punindo a sociedade por obrigação que lhe é estranha, da qual não tomou parte, mas que poderia ser adimplida de outro modo, mediante retenção dos lucros do sócio pelo credor" (Recurso Especial $n^{\circ}$ 1.346.712, Relator Luis Felipe Salomão, julgado pela Quarta Turma do Superior Tribunal de Justiça em 04/11/2016)..
} 
Revista Eletrônica de Direito Processual - REDP.

Rio de Janeiro. Ano 11. Volume 18. Número 3. Setembro a Dezembro de 2017

Periódico Quadrimestral da Pós-Graduação Stricto Sensu em Direito Processual da UERJ

Patrono: José Carlos Barbosa Moreira. ISSN 1982-7636. pp. 219-237

www.redp.uerj.br

tentar equalizar os interesses da sociedade, dos sócios e dos credores, procurando encontrar

uma forma menos gravosa a todos, harmonizando-se os interesses do credor e da sociedade, buscando a preservação desta.

Portanto, percebe-se da interpretação dos dispositivos ora estudados que é possível a penhora de quotas nas sociedades simples para tão somente transformar a quota social (bem imaterial do sócio) em dinheiro, não podendo o credor ingressar como sócio ao penhorar dita quota, ao contrário do que pode acontecer nos casos de penhora de quotas das sociedades limitadas.

\section{Os problemas relativos ao procedimento da penhora e alienação de quotas de ações de sociedades personificadas na perspectiva dos direitos fundamentais das partes.}

A redação do artigo 861 do Código de Processo Civil não encontra correspondência no ordenamento jurídico anterior, de modo que constitui regramento jurídico novo.

Nesse sentido, o artigo ora debatido também estabelece, em evidente hipótese de flexibilização procedimental, calcado nas exigências de efetividade do processo, de respeito ao direito fundamental ao contraditório, ao dever de motivação das decisões judiciais e ao princípio da preservação da empresa e à affectio societatis ${ }^{36}$, em fórmula forjada de modo a permitir a possibilidade de adequação ao objeto do debate ${ }^{37}$. É nesse sentido que, de forma pormenorizada, observa-se que a aplicação do procedimento previsto no artigo 861 pressupõe, em primeiro lugar, que se faça a apuração do valor atual da quota ou ação - e é nesse sentido que se estabelece, em primeiro lugar, o prazo de três meses supracitado, no qual a primeira tarefa consiste na apresentação de balanço especial. $\mathrm{O}$ procedimento em questão guarda simetria com a fórmula prevista no art. 1.031 do Código Civil/2002, e sua complexidade justifica o reconhecimento, pelo legislador, de que não se trata de providência que possa ser implementada sem que se respeite prazo razoável ${ }^{38}$.

\footnotetext{
${ }^{36}$ Essa é a leitura também de Guilherme Peres de Oliveira, Sergio Mattos, in WAMBIER, Teresa Arruda Alvim, DIDIER JR, Fredie, TALAMINI, Eduardo e DANTAS, Bruno (org.). Breves Comentários ao Novo Código de Processo Civil. Op. cit., p. 1971 e de THEODORO JR., Humberto. Curso de Direito Processual Civil. Vol. III. 47 edição. Rio de Janeiro: Forense, 2015. p. 499.

${ }^{37}$ Sobre a ideia de adequação, ver os ensinamentos de LACERDA, Galeno. O Código como sistema legal de adequação do processo. Revista comemorativa do cinquentenário do Instituto dos Advogados do Rio Grande do Sul (1976): 161-170, passim.

${ }^{38}$ A respeito da possibilidade de ampliação do prazo legal, adere-se às conclusões de AMARAL, Guilherme Rizzo. Comentários às Alterações do Novo CPC. São Paulo: Revista dos Tribunais, 2015. p. 879.
} 
Revista Eletrônica de Direito Processual - REDP.

Rio de Janeiro. Ano 11. Volume 18. Número 3. Setembro a Dezembro de 2017

Periódico Quadrimestral da Pós-Graduação Stricto Sensu em Direito Processual da UERJ

Patrono: José Carlos Barbosa Moreira. ISSN 1982-7636. pp. 219-237

www.redp.uerj.br

Apurado o valor das quotas ou ações, impõe-se a oferta aos sócios. A providência em questão é fundamental em se tratando de sociedade de pessoas, mas pressupõe a existência de cláusula contratual específica contemplando esse direito de preferência. Em tais sociedades, inexistindo manifestação de opção de compra pelos sócios, três alternativas surgem. A primeira delas, na forma do art. $861, \S 1^{\circ}$, é a aquisição das quotas ou ações pela própria sociedade, com preferência, o que fica condicionado ao fato de tal aquisição ser feita mediante o emprego de reservas e sem redução do capital social. A segunda possibilidade a ser considerada é a liquidação das quotas ou ações, com o depósito dos valores correspondentes em juízo, na forma do art. 861, III, o que traz consigo a redução do capital social e do patrimônio da sociedade.

A terceira possibilidade a ser aventada, que é de aplicação subsidiária e que tem sua aplicação condicionada ao fato da liquidação das quotas ou ações se revelar excessivamente onerosa para a sociedade, é a realização de leilão judicial, na forma do art. $861, \S 5^{\circ}$. Essa alternativa, contudo, resta possível exclusivamente em se tratando de aquisição das quotas em circunstâncias nas quais não se quebre o vínculo pautado na affectio societatis.

Segundo o Superior Tribunal de Justiça, a penhora pode recair sobre as quotas de sociedade limitada, "ainda que exista vedação no contrato social da sociedade empresária à livre alienação das quotas, sem que isso, contudo, implique a admissão como sócio daquele que arrematar ou adjudicar" ${ }^{\prime 3}$. A manutenção da orientação jurisprudencial em questão faz com que a aquisição das quotas em leilão, prevista no parágrafo quinto do art. 861, somente possa ser feita de modo a não violar o caráter pessoal inerente a tais sociedades. Observa-se, no caso, um verdadeiro confronto de direitos fundamentais, sendo perceptível a preocupação com a forma como a livre iniciativa dos sócios remanescentes deve conviver com o exercício da liberdade negocial ou da autonomia privada (individual) do sócio que teve suas quotas penhoradas ${ }^{40}$.

A preocupação com a preservação da atividade empresarial, que é outro fator fundamental a permear a exegese do art. $861, \S \S 4^{\circ}$ e $5^{\circ}$, justifica, ainda, que a condução do

\footnotetext{
${ }^{39}$ Recurso Especial no 221.665/SP, Relatora Ministra Fátima Nancy Andrighi, julgado pela Terceira do Superior Tribunal de Justiça em 07/05/2011.

${ }^{40}$ MARTINS-COSTA, Judith Hofmeister. Os direitos fundamentais e a opção culturalista do novo Código Civil. In: SARLET, Ingo Wolfgang (org.). Constituição, direitos fundamentais e direito privado Porto Alegre: Livraria do Advogado, 2003. p. 97.
} 
Revista Eletrônica de Direito Processual - REDP.

Rio de Janeiro. Ano 11. Volume 18. Número 3. Setembro a Dezembro de 2017

Periódico Quadrimestral da Pós-Graduação Stricto Sensu em Direito Processual da UERJ

Patrono: José Carlos Barbosa Moreira. ISSN 1982-7636. pp. 219-237

www.redp.uerj.br

processo de liquidação não seja sujeita ao rígido limite do prazo imposto no caput do referido comando legal. A preocupação em buscar equivalência mínima entre o valor apurado das quotas ou ações e o saldo dos lucros e reservas tem por objetivo preservar a saúde econômica da sociedade, fazendo com que sua atividade permaneça inalterada.

A preservação do capital social, na forma do art. 861, § $4^{\circ}$, I é vista como indício da manutenção das condições de continuidade da atuação da sociedade. Esse também é o espírito subjacente ao art. $861, \S 4^{\circ}$, II, ao afirmar que o pagamento das quotas ou ações liquidadas não pode acarretar, como resultado, o surgimento de risco (o que, nesse ponto, não pressupõe a existência de prejuízo já verificado, mas apenas a presença de tal perspectiva) à estabilidade financeira da sociedade simples ou empresária.

Ademais, o parágrafo quinto do artigo em exame determina a possibilidade do juiz determinar o leilão judicial das quotas ou ações para aquelas hipóteses em que nenhuma das outras formas de expropriação seja capaz de realizar o crédito executado sem impor maior prejuízo à vida da sociedade que teve suas quotas penhoradas. Assim, se não houver interesse dos demais sócios no exercício de direito de preferência, não ocorrer a aquisição das quotas ou das ações pela sociedade e a liquidação do inciso III do caput for excessivamente onerosa para a sociedade, o juiz terá a opção de determinar o leilão judicial.

Logo, a medida facultada por meio do art. 861, § $5^{\circ}$, deve, entretanto, ser vista como uma solução de caráter subsidiário, uma vez que terceiros, estranhos à sociedade, teriam a possibilidade de fazer parte dela por meio da aquisição de quotas em leilão. Para além das dificuldades práticas relativas à presença de interessados na aquisição de bens penhorados (que se fazem presentes, a bem da verdade, também em outros contextos) $)^{41}$, a providência enseja críticas tendo em vista as dificuldades de inclusão de sócios em sociedades nas quais o objeto social depende dos atributos dos sócios ou nos casos de vedação contratual à admissão de novo sócio em razão da oposição dos demais. Partindo dessa premissa, é de se cogitar que os demais sócios possam, em tais casos, apresentar oposição à penhora por meio de embargos de terceiro, ou, ainda, poderão manejar ação de dissolução parcial de sociedade, caso optem pelo direito de retirada.

\footnotetext{
${ }^{41}$ Essa dificuldade é registrada por Renato Rodrigues Filho, in CUNHA, José Sebastião Fagundes (coord). Código de Processo Civil Comentado. São Paulo: Revista dos Tribunais, 2015. p. 1206-1207.
} 
Revista Eletrônica de Direito Processual - REDP.

Rio de Janeiro. Ano 11. Volume 18. Número 3. Setembro a Dezembro de 2017

Periódico Quadrimestral da Pós-Graduação Stricto Sensu em Direito Processual da UERJ

Patrono: José Carlos Barbosa Moreira. ISSN 1982-7636. pp. 219-237

www.redp.uerj.br

Não obstante, importa esclarecer que em se tratando de sociedade anônima de

capital aberto, o procedimento a ser respeitado vem previsto no parágrafo segundo do artigo 861, e leva em conta o fato de se tratar de verdadeira sociedade de capitais, na qual pouco importa a identidade do sócio para a sua existência, preterido em detrimento da preocupação com a existência de aporte financeiro necessário para a consecução dos fins societários. A primeira alternativa prevista no comando em questão é a possibilidade de adjudicação das ações ao exequente, que se coloca com posição de preferência em tal contexto. Caso não exercida essa preferência, as ações podem ser alienadas em bolsa de valores, como sói acontecer nos casos em que os sócios buscam especular em cima da cotação de tais títulos. A predeterminação do preço das ações por força da avaliação de mercado faz com que o procedimento se revele mais singelo nessa última alternativa. $\mathrm{O}$ referido gravame judicial poderá ser averbado, para conhecimento de terceiros, nos registros de ações da companhia e nos assentos da Junta Comercial onde o contrato tiver sido registrado ${ }^{42}$.

O legislador prevê, no art. $861, \S 3^{\circ}$, a possibilidade de nomeação de administrador para os fins de desenvolvimento da atividade de liquidação das quotas ou ações de sociedade, regra cuja aplicabilidade resta adstrita aos casos de a penhora recair sobre quotas ou ações de sociedades de pessoas, que não possuem cotação em bolsa ou valor de mercado predeterminado. Em tal hipótese, que pressupõe requerimento do exequente ou da sociedade, deverá o referido administrador submeter à aprovação judicial a forma de liquidação das quotas ou ações, e devem os sócios e a sociedade serem intimados das decisões prolatadas nos autos ${ }^{43}$, por amor ao direito fundamental ao contraditório, em especial nos casos em que a alienação coloque em risco a affectio societatis.

Por fim, é de se anotar que o sócio que teve suas quotas penhoradas esteja impedido de exercer o direito de voto em assembleia. A rigor, não se pode ignorar que o

\footnotetext{
42 THEODORO JR., Humberto. Curso de Direito Processual Civil. Vol. III. $47^{\mathrm{a}}$ edição. Rio de Janeiro: Forense, 2015. p. 499.

${ }^{43}$ Assim AMARAL, Guilherme Rizzo. Comentários às Alterações do Novo CPC. São Paulo: Revista dos Tribunais, 2015. p. 879 .
} 
Revista Eletrônica de Direito Processual - REDP.

Rio de Janeiro. Ano 11. Volume 18. Número 3. Setembro a Dezembro de 2017

Periódico Quadrimestral da Pós-Graduação Stricto Sensu em Direito Processual da UERJ

Patrono: José Carlos Barbosa Moreira. ISSN 1982-7636. pp. 219-237

www.redp.uerj.br

depósito das ações em penhora não é translativo da sua propriedade, mas apenas ato processual executivo preparatório com vistas a tal desiderato ${ }^{44}$.

\section{Conclusão}

Ao final do presente estudo, vê-se que a equação a ser feita com vistas à viabilização da penhora de quotas de sociedades personificadas é um desafio hercúleo. Das problemáticas elencadas resulta, como conclusão inevitável, que o advento de legislação tratando do tema de forma alguma esgota os desafios práticos daqueles que se deparam com tais questões na seara forense. A sofisticação da sistemática societária e os limites inerentes às fórmulas processuais não devem servir como obstáculos à necessária criatividade que deve pautar o olhar daqueles que se deparam com os dilemas a serem solucionados.

Dentre os argumentos que se destacam na construção do debate em torno da viabilidade e efetividade da penhora de quotas de sociedade personificada, destacam-se sempre a preocupação com a affectio societatis e a preocupação com a continuidade da atividade empresarial. É inegável que tais fatores exercem peso crucial na conformação de um processo que se pretenda influenciado pela exigência de respeito ao direito fundamental à tutela jurisdicional efetiva, entendida como compromisso com um processo conformado de modo a atender não apenas à exigência de celeridade, mas, antes, de prolação de decisões capazes de oferecer soluções justas. Essa perspectiva qualitativa em relação ao conteúdo da tutela jurisdicional faz com que os limites estabelecidos pelo legislador devam ser sempre lidos de modo a garantir às partes um processo que não se limite a simplesmente expropriar bens a qualquer preço, mas, antes, que permita a satisfação do crédito sem que isso importe em simples desmonte da atividade desenvolvida no âmbito societário. O equilíbrio no atendimento a tais exigências é, pois, o desafio a ser enfrentado.

Uma perspectiva a ser considerada como fórmula que permite contornar muitas das dificuldades práticas anotadas consiste no emprego de fórmulas atípicas executivas forjadas a partir do constante do art. 139, IV, do CPC. A abertura de catálogo

\footnotetext{
${ }^{44}$ THEODORO JR., Humberto. Curso de Direito Processual Civil. Vol. III. $47^{\mathrm{a}}$ edição. Rio de Janeiro: Forense, 2015. p. 498.
} 
Revista Eletrônica de Direito Processual - REDP.

Rio de Janeiro. Ano 11. Volume 18. Número 3. Setembro a Dezembro de 2017

Periódico Quadrimestral da Pós-Graduação Stricto Sensu em Direito Processual da UERJ

Patrono: José Carlos Barbosa Moreira. ISSN 1982-7636. pp. 219-237

www.redp.uerj.br

proporcionada pelo comando legal mencionado, permitindo o emprego de medidas executivas atípicas, pode servir como válvula de escape para albergar soluções que não caibam dentro dos rígidos moldes tipificados pelo legislador no art. 861 do CPC. O citado art. 139, IV serve como indicativo de densificação do direito fundamental à tutela jurisdicional efetiva, assegurando às partes a possibilidade de que soluções criativas não contempladas pelo legislador possam ser utilizadas de modo que a execução não gere um simples desmonte da atividade empresarial até então desenvolvida e, ao mesmo tempo, seja igualmente capaz de satisfazer o interesse do credor em receber os créditos que lhe são devidos. De se pensar, nesse sentido, a título exemplificativo, na possibilidade de utilização, sob o pálio da fórmula ora cotejada, de fórmulas híbridas que permitam a conjugação de estratégias de liquidação de quotas, de aquisição de quotas pela sociedade e de aquisição de quotas pelos sócios com forma de gerar em favor do exequente as quantias de que é credor. Da mesma forma, a construção de outras soluções negociadas, construídas sob a perspectiva do art. 190 do CPC, também devem ser consideradas como alternativas preferíveis no contraste com outras fórmulas que imponham a indesejável alienação de quotas em favor de terceiros naqueles casos em que esteja em risco a affectio societatis ou a continuidade da atividade empresarial.

\section{REFERÊNCIAS BIBLIOGRÁFICAS:}

ABELHA, Marcelo. Manual de Execução Civil. $5^{\text {a }}$ edição. Rio de Janeiro: Forense, 2015. ABRÃO, Nelson. Sociedades limitadas. Atualizado por Carlos Henrique Abrão. 9. ed. São Paulo: Saraiva, 2005.

ADIERS, Moacir. Dissolução parcial de sociedade civil por quotas de responsabilidade limitada. Revista Jurídica, no 280 (2001): 61-72.

AMARAL, Guilherme Rizzo. Comentários às Alterações do Novo CPC. São Paulo: Revista dos Tribunais, 2015.

ASSIS, Araken de. Manual da Execução. 13ª ed., São Paulo: Revista dos Tribunais, 2006.

ASSIS, Araken de. Cumprimento da sentença. Rio de Janeiro, Forense, 2006.

ÁVILA, Humberto. Teoria dos princípios. São Paulo: Malheiros, 2003.

BARBOSA MOREIRA, José Carlos Barbosa. Efetividade do processo e tecnica processual. Revista de Processo, vol. 77 (1995): 168-176. 
Revista Eletrônica de Direito Processual - REDP.

Rio de Janeiro. Ano 11. Volume 18. Número 3. Setembro a Dezembro de 2017

Periódico Quadrimestral da Pós-Graduação Stricto Sensu em Direito Processual da UERJ

Patrono: José Carlos Barbosa Moreira. ISSN 1982-7636. pp. 219-237

www.redp.uerj.br

BARBOSA MOREIRA, José Carlos. Efetividade do processo: Por um processo

socialmente efetivo. Revista Sintese de Direito Civil e Processual Civil. vol. 11 (2001): 5-14.

CAMPINHO, Sérgio. O direito da empresa à luz do novo Código Civil. $4^{\mathrm{a}}$. ed. Rio de Janeiro: Renovar, 2004.

COELHO, Fábio Ulhoa. Curso de Direito Comercial. Direito de Empresa. Vol. 2. 15 a ed. São Paulo: Saraiva, 2011.

CUNHA, José Sebastião Fagundes (coord). Código de Processo Civil Comentado. São Paulo: Revista dos Tribunais, 2015.

FRANCO, Vera Helena de Mello. Lições de Direito Comercial. 2.ed. São Paulo: Maltese, 1995.

GONÇALVES NETO. Alfredo de Assis. Direito de Empresa. $3^{\text {a }}$ ed. São Paulo: Revista dos Tribunais, 2010.

GRAZIANI, Alessandro. Diritto delle Societá. 5.ed.Nápoli:Morano, 1963.

LACERDA, Galeno. O Código como sistema legal de adequação do processo. Revista comemorativa do cinquentenário do Instituto dos Advogados do Rio Grande do Sul (1976): 161-170.

LEÃES, Luiz Gastão Paes de Barros. Exclusão extrajudicial de sócio em sociedade por quotas. Revista de Direito Mercantil: Industrial, Econômico e Financeiro, vol. 100 (1995): 85- 97.

LOBO, Jorge. Sociedades limitadas. Vol. 1. Rio de Janeiro: Forense, 2004.

LUCENA, José Waldecy. Das sociedades limitadas. 6.ed. Rio de Janeiro: Renovar, 2004.

MARINONI, Luiz Guilherme. A legitimidade da atuação do juiz a partir do direito fundamental à tutela jurisdicional efetiva. In: MEDINA, José Miguel Garcia; CRUZ, Luana Pedrosa de Figueiredo; CERQUEIRA, Luís Otávio Sequeira De; Gomes Júnior, Luiz Manoel (coord.)..Os poderes do juiz e o controle das decisões judiciais: estudos em homenagem à professora Teresa Arruda Alvim Wambier, São Paulo : Rev. dos Tribunais, 2008. p. 229-236.

MARINONI, Luiz Guilherme; ARENHART, Sérgio Cruz; MITIDIERO, Daniel. Novo Curso de Processo Civil. v.3. $2^{\text {a }}$ ed. São Paulo: Revista dos Tribunais, 2016. 
Revista Eletrônica de Direito Processual - REDP.

Rio de Janeiro. Ano 11. Volume 18. Número 3. Setembro a Dezembro de 2017

Periódico Quadrimestral da Pós-Graduação Stricto Sensu em Direito Processual da UERJ

Patrono: José Carlos Barbosa Moreira. ISSN 1982-7636. pp. 219-237

www.redp.uerj.br

MARTINS-COSTA, Judith Hofmeister. Os direitos fundamentais e a opção culturalista do

novo Código Civil. In: SARLET, Ingo Wolfgang (org.) Constituição, direitos fundamentais e direito privado Porto Alegre: Livraria do Advogado, 2003.

PENTEADO, Mauro Rodrigues. Dissolução e Liquidação de Sociedades: Dissolução Parcial. v.1. $2^{\mathrm{a}}$. ed. São Paulo: Saraiva, 2000.

REQUIÃO, Rubens. Aspectos modernos de Direito Comercial. I. São Paulo, Saraiva: 1977.

SIMÃO FILHO, Adalberto. A Nova Sociedade Limitada. Barueri-SP: Manole, 2004.

TOMAZETTE. Marlon. Curso de Direito Empresarial. Teoria Geral e Direito Societário. Vol. I. $3^{\text {a }}$ ed. São Paulo: Atlas, 2011.

THEODORO JR., Humberto. Curso de Direito Processual Civil. Vol. III. 47 a edição. Rio de Janeiro: Forense, 2015.

WAMBIER, Teresa Arruda Alvim, DIDIER JR, Fredie, TALAMINI, Eduardo e DANTAS, Bruno (org.). Breves Comentários ao Novo Código de Processo Civil. São Paulo: Revista dos Tribunais, 2015. 